\title{
Equilibrium
}

Quarterly Journal of Economics and Economic Policy

VOLUME 8 ISSUE 3, 2013

ISSN 1689-765X, (Online) ISSN 2353-3293

http://www.equilibrium.umk.pl/

Jodkowska L. (2013), Inclusion and Integration of the Disabled into the Labor Market Against the Background of the New Regulations in Germany, "Equilibrium. Quarterly Journal of Economics and Economic Policy”, Volume 8, Issue 3, pp. 79-101, DOI: $\underline{\text { http://dx.doi.org/10.12775/EQUIL.2013.021 }}$

\section{Inclusion and Integration of the Disabled into the Labor Market Against the Background of the New Regulations in Germany}

JEL Classification: $J 59$

Keywords: labour market, disabled, regulation

Abstract: The aim of the article is to present new regulations introduced by the Third Book of the Social Code in Germany that concern a reform of the labor market's active instruments gathered under the name "Instumentenreform".

One of the main objectives of the reform is to improve the quality of programs and projects that activate the unemployed, but also to make efforts to include in the labor market groups that have not been activated in such a way so far. One of such groups are the disabled trained and employed in Invalids' Cooperatives.

One of the further, and at the same time new, criteria for all organizations and institutions receiving and applying for funds to realize programs of the labor market and vocational trainings is the introduction and certification of the quality management system.

The aim of the paper is to compare the activity of Invalids' Cooperatives in Poland and Germany. This aim will be carried out by analyzing the regulations and as far as possible the data available (the regulations became effective in two stages: in April 2012, and since 01.01.2013 onwards).

The findings of the article have been collected in the form of a description of the situation and forecast for 2013.

(C) Copyright Institute of Economic Research \& Polish Economic Society Branch in Torun Date of submission: January 1, 2013; date of acceptance: August 12, 2013

*Contact: jodkows@htw-berlin.de, Hochschule für Technik und Wirtschaft, Treskowallee 8, Berlin, Germany 


\section{Introduction}

According to a recent WHO report, "about $15 \%$ of the world's population lives with some form of disability, of whom $2-4 \%$ experience significant difficulties in functioning" (World Report on Disability 2011). Thus, this amount exceeds the WHO estimate of 1970 (expected value of about 10\%), and is conditional upon diseases associated with the ageing population and the prevalence of chronic diseases ${ }^{1}$.

Disability is often linked to discrimination and may relate to any age group or gender. The Convention on the Rights of Persons with Disabilities, drafted in New York on 13 December 2006 aims to protect all people with disabilities, to enable them to participate in society, to facilitate their inclusion in the labor market while protecting them against discrimination based on the type and degree of disability.

Due to the diversity of the groups covered by the above-mentioned Convention (including respect for difference, and acceptance of people with disabilities as part of human diversity and humanity, respect for the evolving capacities of children with disabilities and respect for the right of children with disabilities to preserve their identities) and the extent of its interference in the life of society (respect for inherent dignity, individual autonomy including the freedom to make one's own choices, and independence of persons, non-discrimination and equality of opportunity) (The Convention on the Rights of Persons with Disabilities, art. 3), the subject of the present work has been limited to the description and analysis of the situation of people with disabilities and their integration into the labor market in Germany in comparison with Poland.

The thesis of this paper is the assumption that the legal acts governing inclusion of people with disabilities into the labor market regulate the inclusion on the basis of acts and regulations in theory, whereas in practice there is still great potential with regard to achieving inclusion of people with disabilities, not only in the labor market, but also in society.

The aims of the paper were carried out on the basis of the study of literature, in particular the content of legislation. After defining the group analyzed, its share in the labor market was presented on the basis of data analysis, both in Poland and Germany, indicating particular problems specific to Germany, for example, implementation of regulations by individual regions of Germany. In order to verify the actual situation of people with disabilities and efforts to include them in the labor market, about 10 interviews were conducted with experts, i.e. managers of sheltered workshops and reports were read. Analysis of statistical data and sheltered workshops' feedback confirmed the thesis of the paper.

\footnotetext{
${ }^{1}$ In relation to 1970 methods to measure and classify illnesses are different - more precise - hence forecast's error.
} 


\section{Disability}

The broadest definitions of health and disability have been formulated by the WHO. According to its definition, "Health is a state of complete physical, mental and social well-being, and not merely the absence of disease or infirmity" (Constitution of the World Health Organization). In the case of both countries - Poland and Germany - health is protected, respectively, by the Constitution of the Republic of Poland in Art. 68, in particular paragraph 1 and 3 and in the Basic Law in Art. 2 and Art. 1 SGB V (Health Insurance).

Since the definition of health is very broad, it can be assumed that not every person in the society meets all of the criteria, i.e. is healthy. Therefore, in 1980 the WHO adopted a classification of impairments, disabilities and handicaps collected in a document titled International Classification of Impairments, Disabilities and Handicaps. Types of disabilities were divided into three categories:

"Impairment: in the context of health experience, an impairment is any loss or abnormality of psychological, physiological or anatomical structure or function.

Disability: in the context of health experience a disability is any restriction or lack (resulting from an impairment) of ability to perform an activity in the manner or within the range considered normal for a human being.

Handicap: in the context of health experience a handicap is a disadvantage for a given individual, resulting from an impairment or a disability, that limits or prevents the fulfilment of a role that is normal (depending on age, sex, and social and cultural factors) for that individual" (WHO 1980).

Disability and related impairments may be considered in different categories. Body functions and structures and impairments are divided into three key aspects: biological, functional and social. Figure 1 presents a biopsychosocial model of disability, with corresponding International Classification of Functioning, Disability and Health. 
Figure 1. Biopsychosocial model of disability

\begin{tabular}{|l|c|l|}
\hline SOCIAL & $\begin{array}{c}\text { Culture } \\
\text { Social interactions } \\
\text { The sick role }\end{array}$ & $\begin{array}{l}\text { ICF } \\
\text { Environmental factors } \\
\text { Participation restrictions }\end{array}$ \\
\hline PSYCHOLOGICAL & $\begin{array}{l}\text { Illness behavior } \\
\text { Beliefs, coping strategies }\end{array}$ & $\begin{array}{l}\text { Activity limitations } \\
\text { Personal factors }\end{array}$ \\
\hline BIOLOGICAL & Neurophysiology & $\begin{array}{l}\text { Impairments } \\
\text { Body structures and func- } \\
\text { tions }\end{array}$ \\
\hline
\end{tabular}

Source: As in British Medical Bulletin, Published by Oxford University, http://bmb.oxfordjournals.org/content/77-78/1/55/F1.expansion.html (1.4.2012).

Taking into account the abilities of human body or injuries to it, the ICF classification distinguishes:

impairments - problems in body function or alterations in body structure, for example, paralysis or blindness;

activity limitations - difficulties in executing activities, for example, walking or eating;

participation restrictions - problems with involvement in any area of life, for example, facing discrimination in employment or transportation." (International Classification of Functioning, Disability and Handicaps).

The occurrence of these changes leads to a distortion of the activities of an individual, and may limit his or her participation in society. A diagram of the impact of these factors is presented in Figure 2.

In view of the subject matter analyzed, it can be omitted whether the disability or impairment is congenital or has occurred e.g. as a result of an accident or illness. 
Figure 2. Interactions between the components of ICF

Heath condition

(disorder or disease)

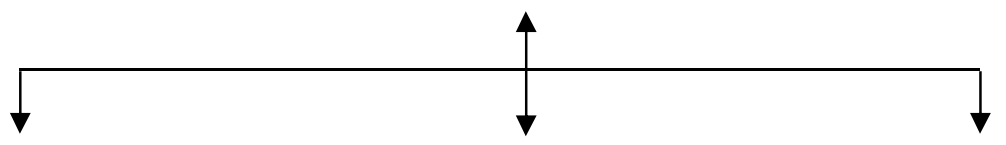

Body

Functions and

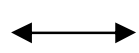

Activities

Participation

Structures

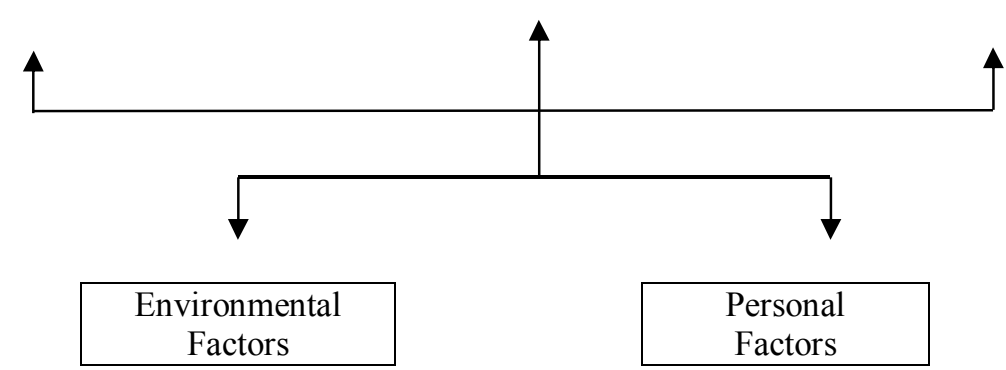

Source: International Classification of Functioning, Disability and Health (ICF), WHO, Geneva (2001, p. 18).

The German definition of disability is formulated in the Social Code Book IX (German: Sozialgesetzbuch IX Buch/SGB IX) and is limited to individuals whose "physical, psychological or mental health is likely to be disturbed for at least six months in relation to the relevant age group, and for this reason participation of the person in society is limited."

Regardless of the degree of disability, people with disabilities have the right to participate in the labor market. Inclusion of this group into the labor market is within the responsibilities of the Labor Office. The Labor Office's task is to support participation of disabled people in their working life and to promote participation of disabled people. Integration on the labor market should be as normal as possible and as special as necessary (Homepage Bundesagentur für Arbeit).

\section{Supporting the Participation of Disabled People in the Labor Market}

Until the end of the 90's of the twentieth century, special protection of the disabled, regulated by the relevant provisions, was the main task of the state and its executive bodies. The German welfare state provides, in particular, 
help to those who, for various reasons, are in such a situation as a result of which they are not able to obtain the income necessary for subsistence (Fürsorgeprinzip). Provisions protecting the unemployed and those unable to work have been formulated so as to be consistent with these requirements. It was not until after the ratification of The Convention on the Rights of Persons with Disabilities of 2006, which took place in Germany in 2009, that special protection of the disabled had evolved in the direction of promoting the integration, or in fact in terms of the English language - inclusion, not only in the labor market, as this applies particularly to inclusion in the society (Teilhabe). Germany is, like Poland, one of the countries that have already established a separate system for children with disabilities at the stage of school education ${ }^{2}$ (The Convention on the Rights of Persons with Disabilities; Gesetz zu dem Übereinkommen der Vereinten Nationen). Regardless of the ratification of the Convention on the Rights of Persons with Disabilities, further reforms and adjustment instruments for the activation of people not participating in the labor market were introduced in Germany, gathered under the common name - literally - "instruments reform" (Instumentenreform) meaning "reform of the instruments of active labor market policies" (Gesetz zur Verbesserung der Eingliederungschancen am Arbeitsmarkt). The changes were initiated by the legislator, the Federal Ministry of Labor and Social Affairs, and the Federal Ministry of Economics and Technology, while one of the main implementing bodies was the Federal Employment Agency (German: Bundesagentur für Arbeit) ${ }^{3}$.

Due to the internal conditions of the labor market, including lack of professionals in certain occupations, demographic changes in society, the relatively low level of general knowledge of graduates of comprehensive schools, who are entitled to undertake vocational training, integration problems among young foreigners and external conditions such as changes in laws and regulations, taking into account the new recommendations, including those given by the European Commission, the Bundesrat has updated the provisions of the Social Code Book III (SGB III). One of the important changes are the regulations pertaining to eligibility for certain benefits (nonpecuniary). In accordance with the previous provisions, those concerned were able to apply for support from the Labor Office and, at the discretion of

\footnotetext{
${ }^{2}$ Terms disabled and handicapped were not distinguished here to make things easier. See WHO definitions.

${ }^{3}$ Further in the text translated names or abbreviations introduced in the text will be used to make things easier.

Further in the text terms „Employment Agency” and „Labor Office” have been used interchangeably. Labor Office is a territorial unit that is financed from the federation's funds, including contributions for unemployment insurance, as opposed to Jobcenter, which is an equivalent to District Labor Office and is financed from municipal funds (and money from taxes).
} 
the officer, could receive a voucher for training courses (Ermessensleistung), and after the reform has the right to obtain e.g. the activation voucher (Aktivierungs- und Vermittlungsgutschein) and use it at a private employment agency $^{4}$.

An important objective of the changes in the reform of the instruments was also focusing on measures to improve the qualifications of young people in the phase of transition from school to vocational training or work (Leyen 2011 , p. 3). Another objective of the reform was to gain annual savings in unemployment benefits amounting to about 2 billion euros (Leyen 2011, p. 4).

Further changes introduced under the last reform, which were to increase the chances of integration on the labor market, include combining selected active labor market policies and transforming access to them from discretionary benefits to a legal claim. The unification concerned i.e. (Gesetzentwurf der Bundesregierung für ein Gesetz zur Verbesserung der Eingliederungschancen am Arbeitsmarkt):

- Integration benefits (Eingliederungszuschuss) paid to employers. The amount may not exceed $50 \%$ of the employee's salary, and is paid for a maximum period of 12 months (for selected groups, including the elderly and people with disabilities, there are other benefits),

- Certification of organizations offering courses and vocational programs that require a voucher for education, including certification of private employment agencies whose services are accepted by the Labor Offices in the form of activation vouchers,

- Funds to start a business,

- Labor market programs under which social utility work (AGH/Arbeitsangelegenheiten) is carried out,

- Benefits for the employer of a long-unemployed person and unemployed groups particularly difficult to integrate ${ }^{5}$. Labor Office covers $75 \%$ of the employee's salary for up to two years during a five-year period. In addition, the costs of the worker's reintegration counselling are covered,

- To support the inclusion of people with disabilities into the labor market, including in the form of funding for adaptation of workstations for disabled persons.

\footnotetext{
${ }^{4}$ Private employment agent receives 2,000 euros from the Labor Office, if he or she can find a job for the candidate. The first installment is paid after 6 weeks, the second after 6 months.

${ }^{5}$ This group includes, in particular: the unemployed up to 25 years of age, women who did not work after giving birth to a child; unemployed at older age $(45+, 50+)$, unemployed with no professional qualifications, no experience or vocational or secondary education; the unemployed who are single parents, the unemployed who are disabled.
} 
Supporting the integration or reintegration of disabled unemployed people into the labor market is regulated in Germany, in particular, by the provisions of $S G B I I I$. Integration of people with disabilities is regulated and additionally supported and protected, in particular by the provisions of $S G B I X$ and detailed regulations of the Labor Office, and also the rules governing the activities of sheltered employment facilities ${ }^{6}$ (see Table 1).

Table 1. Selected legal acts on persons with disabilities

\begin{tabular}{|c|c|c|}
\hline Category & Regulations SGB III & Regulations SGB IX \\
\hline Definition of a disabled person & $\begin{array}{l}\S 19 \text { Disabled people } \\
\text { (1) Disabled within the meaning of } \\
\text { this book are such people whose } \\
\text { chances of participating in the } \\
\text { professional life or further partici- } \\
\text { pation, due to the type or severity } \\
\text { of their disability within the mean- } \\
\text { ing of article } 2 \text { paragraph } 1 \text { of the } \\
\text { Ninth Book, are not only very } \\
\text { much reduced temporarily stop } \\
\text { much, and the reason the support } \\
\text { for participation work life need, } \\
\text { including people with learning } \\
\text { disabilities }\end{array}$ & $\begin{array}{l}\S 2 \text { Disability } \\
\text { (1) People are disabled if their } \\
\text { physical functioning, mental } \\
\text { capacity or mental health are } \\
\text { highly probable to vary for } \\
\text { more than six months from } \\
\text { the typical age for the state } \\
\text { and therefore their participa- } \\
\text { tion in the life of society is } \\
\text { impaired. } \\
\text { They are threatened by disa- } \\
\text { bility if the impairment is } \\
\text { expected }\end{array}$ \\
\hline $\begin{array}{l}\text { General provision of participa- } \\
\text { tion of the disabled in the labor } \\
\text { market }\end{array}$ & $\begin{array}{l}\S 112 \text { Participation in professional } \\
\text { life } \\
\text { (1) For disabled people to services } \\
\text { are provided to encourage partici- } \\
\text { pation in professional life, to } \\
\text { maintain their ability to work, to } \\
\text { improve, to establish or restore } \\
\text { and ensure their participation in } \\
\text { professional life, when it is re- } \\
\text { quired by the type or severity of } \\
\text { the disability. } \\
\S 90 \text { SGB III integration allowance } \\
\text { for disabled and severely disabled } \\
\text { people } \\
\text { (1) For disabled and severely } \\
\text { disabled people, the integration } \\
\text { allowance can amount up to } 70 \\
\text { percent of the earnings considered } \\
\text { and the allowance period of up to } \\
24 \text { months. }\end{array}$ & $\begin{array}{l}\text { Special rules for the participa- } \\
\text { tion of disabled people } \\
\text { (Disability law) } \\
\text { - Protected persons } \S 68 \\
\text { Scope } \\
\text { The regulations of this part } \\
\text { apply to the disabled and } \\
\text { other such disabilities. } \\
\text { - Employment requirement of } \\
\text { employers } § 71 \text { liability of } \\
\text { employers for employment of } \\
\text { disabled persons }\end{array}$ \\
\hline
\end{tabular}

${ }^{6}$ To make things easier, the Polish term was used here. In Germany, these companies act as a limited liability company and public utility. This means that they have legal personality, but do not pursue profits, and if so, they must be used for employees, for example in the form of additional offer of after-work activities (dance classes, swimming pool or other), or for reinvestment or fund containing financial reserve. 
Table 1 continued

\begin{tabular}{|c|c|c|}
\hline Category & Regulations SGB III & Regulations SGB IX \\
\hline & $\begin{array}{l}\text { 2) For severe disabilities (...) their inter- } \\
\text { mediary for lying in her person reasons is } \\
\text { (particularly severely disabled people), the } \\
\text { integration allowance can amount up to } 70 \\
\text { percent of the earnings considered and the } \\
\text { allowance period of up to } 60 \text { months. The } \\
\text { allowance period can, with particularly } \\
\text { severely disabled people who are at the age } \\
\text { of } 55 \text { (completed), be up to } 96 \text { months }\end{array}$ & \\
\hline $\begin{array}{l}\text { Funds for } \\
\text { employment }\end{array}$ & $\begin{array}{l}\text { § } 90 \text { SGB III integration allowance for } \\
\text { disabled and severely disabled people } \\
\text { (3) In determining the amount and duration } \\
\text { of the allowance for disabled and severely } \\
\text { disabled people it is necessary to consider } \\
\text { whether the severely disabled person will } \\
\text { be further employed without legal obliga- } \\
\text { tion or on the employment obligation } \\
\text { according to Part } 2 \text { of the Ninth Book. } \\
\text { (4) After twelve months, the amount of the } \\
\text { allowance is reduced annually by ten } \\
\text { percentage points. It must not fall below } \\
30 \text { percent of the salary considered. The } \\
\text { integration allowance for particularly } \\
\text { severely disabled people is reduced after } \\
24 \text { months. }\end{array}$ & $\begin{array}{l}\text { Chapter } 5 \\
\text { Benefits for participation in work- } \\
\text { ing life to } \S 33 \\
\text { Employee benefits } \S 34 \\
\text { Centers for vocational rehabilitation } \\
\S 35 \\
\text { Duration of benefits } \S 37 \\
\text { Participation of the Federal Em- } \\
\text { ployment Agency } \S 38 \\
\text { Supported Employment } \S 38 \mathrm{a} \\
\text { Services in Sheltered Workshops } \S \\
39 \\
\text { Services and input methods in VET } \\
\S 40 \\
\text { Achievements in the work area to } \S \\
41 \\
\text { Responsibility for services in } \\
\text { sheltered workshops } \\
\text { People } \S 42 \\
\text { and other supplementary benefits } \\
\text { Supplemental Services } ~ 44 \\
\text { Services for livelihood } \S 45 \\
\text { Normal remuneration } \S 47\end{array}$ \\
\hline
\end{tabular}

\section{Actual Participation of People with Disabilities in the Labor Market}

Preparing children and people with disabilities to participate in a society, and to participate in the labor market begins at school. Until now, each country has had its own solutions (Table 2) - either implementing integration (inclusion) of children with disabilities into the public school system, or based on the principle of segregation, i.e. teaching children with disabilities in special schools (Figure 3). 
Table 2. Percentage of learners educated in separate settings in 2010

\begin{tabular}{|l|l|l|l|}
\hline Up to 1.0\% & $\mathbf{1 . 0 1 \% - 2 . 0 \%}$ & $\mathbf{2 . 1 \% - 4 . 0 \%}$ & $\mathbf{4 . 0 1 \%}$ and above \\
\hline Cyprus & Austria & Finland & Belgium \\
\hline Luxembourg & France & Greece & Czech Republic \\
\hline Malta & Oceland & Hungary & Denmark \\
\hline Portugal & Ireland & Netherlands & Estonia \\
\hline Spain & Lithuania & & Germany \\
\hline Italy (2008) & Norway & & Latvia \\
\hline & Poland & & Switzerland \\
\hline & Slovenia & & \\
\hline & Sweden & & \\
\hline & UK & & \\
\hline
\end{tabular}

*Percentages are calculated using the raw data of learners in compulsory education and learners placed in segregated settings.

Source: Mapping the Implementation ... (2011, p. 28).

Figure 3. Evolution of the concept of special pedagogy

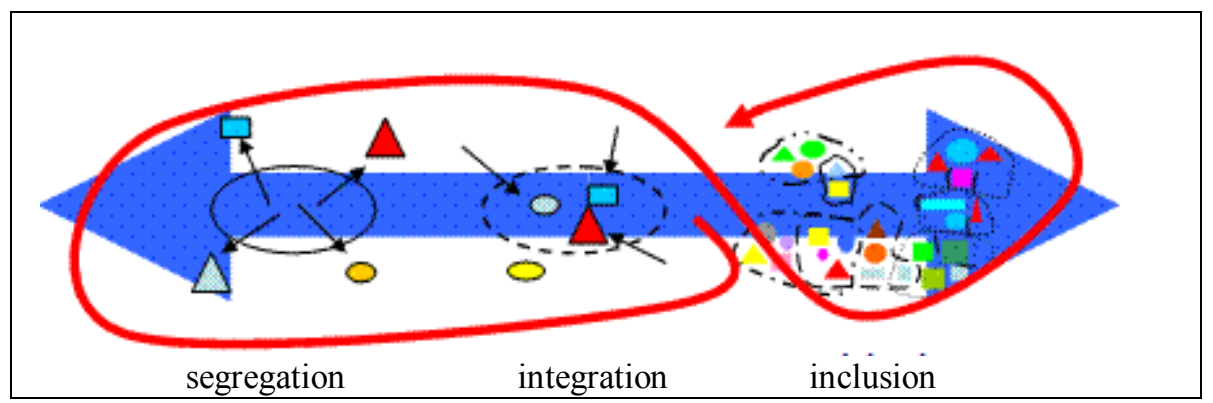

Source: Dreher et al.

Due to the positive results achieved in the field of education in other countries, as well as in a few schools operating in Germany pursuing teaching in integrative classes, and because of the increased efforts to achieve real inclusion, beginning with the school year 2013/2014 disabled children will be attending German public schools, and special schools will be closed. Analysis of learning outcomes showed that in schools pursuing inclusion (according to German statistics about $8 \%$ of all pupils learn in this type of

${ }^{7}$ Data verification based on data from GUS in the paper Oświata $i$ wychowanie w roku szkolnym 2007/2008, GUS, Warszawa 2008, Table 1. (148) p. 297: „Special training and education centers by voivodeships" confirms the data. In Poland there were 352 such centers with 26.854 places (overall numer of students in school year 2007/2008 was 2.4 million), p. 36 . 
school), academic performance of children with disabilities is better or at least comparable with those in special schools, but is never worse (Kunz 2013).

A typically German problem, however, as in many other cases, is the federal system. Each province has developed its own strategy to implement the provisions of the Convention on the Rights of Persons with Disabilities (listed in Table 3), and each state has a slightly different system of education (e.g. in certain provinces, three types of schools have been combined to form a "Gesamtschule"). Another problem is the fact that the inclusion was adopted at the federal level, while the costs of adapting the education system will be borne by the communes. It should foremost be noted that the German education system lacks funds for the renewal (rejuvenating) of the teaching staff. At the same time, to ensure genuine inclusion, there should be at least one additional teacher, or a teacher specializing in special education, in the classroom besides the subject teacher. The additional costs of reconstruction and adaptation of buildings to meet the needs of children with disabilities must be borne by the schools; however, financial considerations cannot be the reason for failure of inclusion (Kunz 2013).

At the moment, in 2013, graduates of special schools have the opportunity to work in one of the 721 sheltered workshops (Behindertenwerkstatt ${ }^{8}$ ) operating in Germany. The requirements to be met by the workshop were collected in "Werkstättenverordnung" (Ordinance on the workshop for disabled people) and include, among others, premises and employees. Each workshop is registered in the Labor Office and is subject to approval process after fulfilling the regulation's requirements (Werkstättenverordnung 2008).

The aim of a sheltered workshop provided for in the act is to provide people with disabilities, who due to the type and degree of disability will not or still cannot be employed in the free labor market, with relevant training and employment corresponding to their abilities, and at the same time allowing for the maintenance or improvement of the ability to work, while being able to develop personality ( $§ 136$ SGB IX).

\footnotetext{
${ }^{8}$ In the Polish system, this term corresponds both to the term and scope of activity of the sheltered workshop, occupational therapy workshop and invalids' cooperative.

Current list: Verzeichnis der anerkannten ... (2012).
} 
Table 3. Strategies for implementing provisions of the Convention on the Rights of Persons with Disabilities by state

\begin{tabular}{|l|l|}
\hline \multicolumn{1}{|c|}{ State } & \multicolumn{1}{c|}{ Actions for implementation } \\
\hline Baden-Württemberg & $\begin{array}{l}\text { The plan will be developed with the national } \\
\text { advisory board for Disabled }\end{array}$ \\
\hline Bavaria & $\begin{array}{l}\text { Draft Plan was developed by the state government } \\
\text { on } 03.05 .2011 \text { and will be further developed with } \\
\text { the cooperation of people with disabilities }\end{array}$ \\
\hline Berlin & The Action Plan was completed in June 2011 \\
\hline Brandenburg & Completion of the plan by the end of 2011 \\
\hline Bremen & $\begin{array}{l}\text { The coalition agreement for } 18 \text { election period } \\
\text { provides for the development of a plan for 2011- } \\
\text { 2014 }\end{array}$ \\
\hline Hamburg & Work in progress \\
\hline Hesse & Plan to be completed by the end of 2011 \\
\hline Mecklenburg-Vorpommern & Work in progres \\
\hline Lower Saxony & $\begin{array}{l}\text { Overview of possibilities for the preparation of an } \\
\text { action plan in progress }\end{array}$ \\
\hline North Rhine-Westphalia & $\begin{array}{l}\text { Completion of works on plan scheduled for sum- } \\
\text { mer 2011 }\end{array}$ \\
\hline Rhineland-Palatinate & Action plan has been in effect since March 2010 \\
\hline Saarland & Work in progress \\
\hline Saxony & Overview of possibilities \\
\hline Saxony-Anhalt & Work in progress \\
\hline Schleswig-Holstein & $\begin{array}{l}\text { The "All together" initiative has been running } \\
\text { since 2006 }\end{array}$ \\
\hline Thuringia & Completion of the plan by the end of 2011 \\
\hline
\end{tabular}

Source: Übereinkommen der Vereinten ... (2011, p. 12).

Sheltered workshops operate regionally and must ensure the workplace for any interested person while meeting the requirements of the principle of diversity. The graduates of special schools, but also people with disabilities who acquired disability due to illness or accident, the mentally ill, including physiotherapists after illness burn out syndrome, people subject to taking medicines during illness or permanently, can apply by themselves, by legal guardians for the place in the cooperative, or they are offered to work in cooperatives from the relevant authority. It is usually Employment Agency, Office of Social Services or the German equivalent of Social Security Office.

Each candidate undergoes a two-step process to adapt to work in the sheltered workshop. After a three-month phase during which the candidate's potential and skills are examined, and during which the candidates can learn about various job positions, e.g. in the department of carpentry, metalworking, assembly, sorting, in the department of textiles and even in the pottery 
or animal care field ${ }^{9}$, the candidate goes to the training department (Berufsbildungsbereich). This name is contractual in nature, because the two-year apprenticeship ends with an internal certificate and entitles primarily to work in a given department of a cooperative (with regard to the candidates' potential it is a simplified curriculum with a reduced range of theoretical issues and does not end up with a professional examination such as in the trade chamber, but only with a certificate).

Adults having previously acquired professional education who, for example as a result of an accident or illness, have lost their abilities do not have to take part in this phase. Regardless of the need to participate in the training, each person is then given permanent employment in cooperatives. Throughout the period of employment, contribution to the social security system is paid, particularly important is the fact of paying contributions for pension insurance.

In 2010, the Employment Agency has obliged, in HEGA 06/2010 document, all active invalids' cooperatives to develop programs and curricula for various professions. Only after the approval was it possible to continue operations. In 2012, in order to ensure and improve the quality of all the instruments of labor market active policy, the obligation to obtain a certificate of quality according to the German system AZAV was introduced ${ }^{10}$. Table 4 summarizes the selected common requirements set out in various regulations that a sheltered workshop must follow.

Table 4. Requirements of relevant regulations

\begin{tabular}{|l|l|}
\hline \multicolumn{1}{|c|}{ WVO requirements } & \multicolumn{1}{c|}{ AZAV \& 2 requirements } \\
\hline - a sheltered workshop must have appropri- & - certified institutions must have a regis- \\
ate equipment and furniture in rooms for & tered seat and, if necessary, may have \\
vocational training & branches with equipment adapted to train- \\
- development of curricula, taking into & ings while maintaining health and safety \\
$\begin{array}{l}\text { account modern forms of education } \\
\text { - qualified staff, } \\
\text { continuous training of staff }\end{array}$ & regulations \\
\hline
\end{tabular}

\footnotetext{
${ }^{9}$ Two last categories are very rare and available, among others, in Brandenburg.

${ }^{10}$ German: Verordnung über die Voraussetzungen und das Verfahren zur Akkreditierung von fachkundigen Stellen und zur Zulassung von Trägern und Maßnahmen der Arbeitsförderung nach dem Dritten Buch Sozialgesetzbuch (Akkreditierungs- und Zulassungsverordnung Arbeitsförderung - AZAV), English: Regulation on the conditions and procedures for the accreditation of competent bodies and accrediting providers and measures of employment promotion to the Third Book of the Social Code (Accreditation and Licensing Regulation, promotion of employment $-A Z A V)$.
} 
Table 4 continued

\begin{tabular}{|l|l|}
\hline $\begin{array}{l}\text { - demonstration of staff's pedagogic skills } \\
\text { (in addition to professional training it is } \\
\text { required to train employees in the field of } \\
\text { special pedagogy) }\end{array}$ & $\begin{array}{l}\text { - trainings must be done only by people with } \\
\text { proper professional and pedagogical qualifi- } \\
\text { cations (management and teachers must also } \\
\text { demonstrate practical experience in the field } \\
\text { of adult education) }\end{array}$ \\
\hline \multicolumn{1}{|c|}{ HEGA 06/10 requirements } & \multicolumn{1}{|c|}{ AZAV § 2 requirements } \\
\hline $\begin{array}{l}\text { - carrying out with a candidate a test } \\
\text { embracing the candidate's potential, pri- } \\
\text { marily designed to demonstrate the candi- } \\
\text { date's abilities and qualify him/her to } \\
\text { vocational training that suits his/her inter- }\end{array}$ & $\begin{array}{l}\text { - test that includes familiarization with the } \\
\text { qualifications, motivation to take up training } \\
\text { and real possibilities of training completion } \\
\text { by the candidate }\end{array}$ \\
$\begin{array}{l}\text { - having a program and a curriculum } \\
\text { - demonstrating a knowledge of current } \\
\text { trends in the labor market, new challenges } \\
\text { in professional life and changes in the } \\
\text { labor market, as well as demonstrating } \\
\text { cooperation with regional and national } \\
\text { firms and actors in the labor market }\end{array}$ & $\begin{array}{l}\text { - curriculum } \\
\text { cooperation with entities that operate in the } \\
\text { panies active in the labor market at the local } \\
\text { level in order to ensure integration }\end{array}$ \\
\hline
\end{tabular}

Source: Own study based on relevant regulations.

Invalids' cooperatives have obligations under the previously mentioned regulations, including striving to integrate people with disabilities into the labor market. In practice, these aspirations are marginal to the labor market. The last available report taking this subject is from 2008, and in Germany it shows an average annual amount of integration in the labor market of only $0.15 \%$ (Table 5).

Table 5. Percentage of people employed in cooperatives who took up a job in global labor market in years $2002-2006$ by states

\begin{tabular}{|l|c|c|c|}
\hline \multicolumn{1}{|c|}{ State } & $\begin{array}{c}\text { Number of } \\
\text { cooperatives }\end{array}$ & $\begin{array}{c}\text { Number of employed } \\
\text { (annual average) }\end{array}$ & Percentage \\
\hline Baden-Württemberg & 52 & 15.678 & 0.16 \\
\hline Bavaria & 74 & 19.420 & 0.08 \\
\hline Berlin & 16 & 5.886 & 0.15 \\
\hline Brandenburg & 25 & 7.897 & 0.07 \\
\hline Bremen & 3 & 2.593 & 0.08 \\
\hline Hamburg & 4 & 2.956 & 0.37 \\
\hline
\end{tabular}

${ }^{11}$ This is to prevent the breach of contract for training by a trainee and to reduce costs. An unemployed participant receives funding for training and at the same time maintenance. It is also assumed that the increase of professional qualifications will improve the chances of integration into the labor market and by taking up a job the Employment Agency will save costs. 
Table 5 continued

\begin{tabular}{|l|c|c|c|}
\hline \multicolumn{1}{|c|}{ State } & $\begin{array}{c}\text { Number of } \\
\text { cooperatives }\end{array}$ & $\begin{array}{c}\text { Number of employed } \\
\text { (annual average) }\end{array}$ & Percentage \\
\hline Hesse & 36 & 11.339 & 0.18 \\
\hline Mecklenburg-Vorpommern & 14 & 5.010 & 0.07 \\
\hline Lower Saxony & 49 & 19.702 & 0.11 \\
\hline North Rhine-Westphalia & 80 & 48.769 & 0.06 \\
\hline Rhineland-Palatinate & 26 & 9.879 & 0.14 \\
\hline Saarland & 10 & 2.994 & 0.32 \\
\hline Saxony & 37 & 8.551 & 0.03 \\
\hline Saxony-Anhalt & 12 & 3.333 & 0.13 \\
\hline Schleswig-Holstein & 22 & 7.039 & 0.22 \\
\hline Thuringia & 22 & 5.540 & 0.04 \\
\hline Total & 482 & 176.586 & 0.15 \\
\hline
\end{tabular}

Source: Detmar et.al. (2008, p. 115).

The number of sheltered workshops has been rising steadily in the recent years. Between 1998 and 2000, 287 workshops were operating, rising to over 700 in 2011. It should also be noted that sheltered workshops play important social roles - allowing people with disabilities to contact other people. However, being the only source of income, they do not provide disabled people enough income to live on. They do not support full integration on the labor market, either. Nevertheless, sheltered workshops play very important role in the process of employing person with severe disability. In that case, it is essential to view work as a factor adding meaning to the whole existence, structuring the daily schedule and facilitating contacts with other members of society (Westecker, Voß 2011).

After conducting ten interviews with experts - managers of the sheltered workshops - in the second half of 2012 and the first quarter of 2013 - and analyzing the documentation, a conclusion has been drawn that the aim was to find 2-4 trainee positions for professional development. Such goals were realistic, as employers are extremely anxious about hiring people with disabilities. Such concerns are due to strict regulations regarding dismissal of the disabled employee and, above all, additional support for people with disability from other employees and possible costs of workplace adaptation.

Sheltered workshops share in the labor market, or rather economic process, is generally not voiced publicly. It includes services for public entities, such as cleaning and maintenance of green areas belonging to universities, like Stephanus-Werkstätten in Berlin, serving meals to patients of Nettetal hospital, simple crafts, packing or assembling, e.g. for well-recognized German and foreign corporations, like Saturn, Mediamarkt, Daimler, Dextro Energy International, Katjes, Tchibo, Ikea, and others (Werkstätten werden zu Dienstleistern der Wirtschaft). 
For employers, such cooperation bears some risk, as the disabled are less immune to stress and workload. On average, there are 450 educational workers, counselors and professional craftsmen per 2,000 disabled employees. Between 1996 and 2012 not only has the number of workshops increased, but also they generated more profits (DM 1,6 billion in 1996, over $€$ 1 billion in 2011) (Die Behindertenwerkstätten sind zu modernen Betrieben geworden).

For the people with severe or moderate disabilities, more adequate solution can be employment in a free market enterprise. All business entities, including public administration, employing more than 20 people are obliged to have at least $5 \%$ of disabled employees ( $\$ 71$ SGB IX). Enterprises not fulfilling the requirement deducted in 2012 between $€ 115$ and $€ 290$ monthly- depending on the number of disabled employees - with employment level below $2 \%$ per employee.

The obstacle concerning employing people with disabilities is their special protection provided for by the legislator. It includes longer notice period and obligatory involvement of the Office for Integration (Integrationsamt) in the process, longer holidays and appointing company plenipotentiary for disabled people (in the case of at least 5 disabled employees).

On the other hand, enterprises employing the disabled may obtain means for workplace adaptation to the disabled person's abilities, especially upgrading infrastructure.

Enterprises employing people with disabilities may also apply for funds to employ assistant of the disabled (Work Assistance) under $\S \S 33,104$ SGB $I X$. Assistant's task is mainly supporting people with physical disabilities, for example the sign language translator for a person with hearing impairment, or a lector for a person with impaired vision. Support and intermediation is provided by Office for Integration.

According to World Report on Disability 2011, it is incorrect to assume that the disabled are less efficient than other workers (World Report on Disability 2011, p. 240). However, this assumption is the main reason why employers are reluctant to employ people with disabilities, and the reason why disabled workers are not being promoted. Nowadays, in view of shrinking societies of developed countries, it is important to effectively introduce, educate and include all human resources.

Since 2009, the number of unemployed people with disabilities has been on the increase (see Figure 4), the trend being outcome of ageing society, and the resulting disabilities of different type and form. The growth of this group is also caused by the end of pre-retirement programs and defining these people as the unemployed (Amtliche Nachrichten der Bundesagentur für Arbeit). 
Figure 4. Unemployed and employed people with disabilities

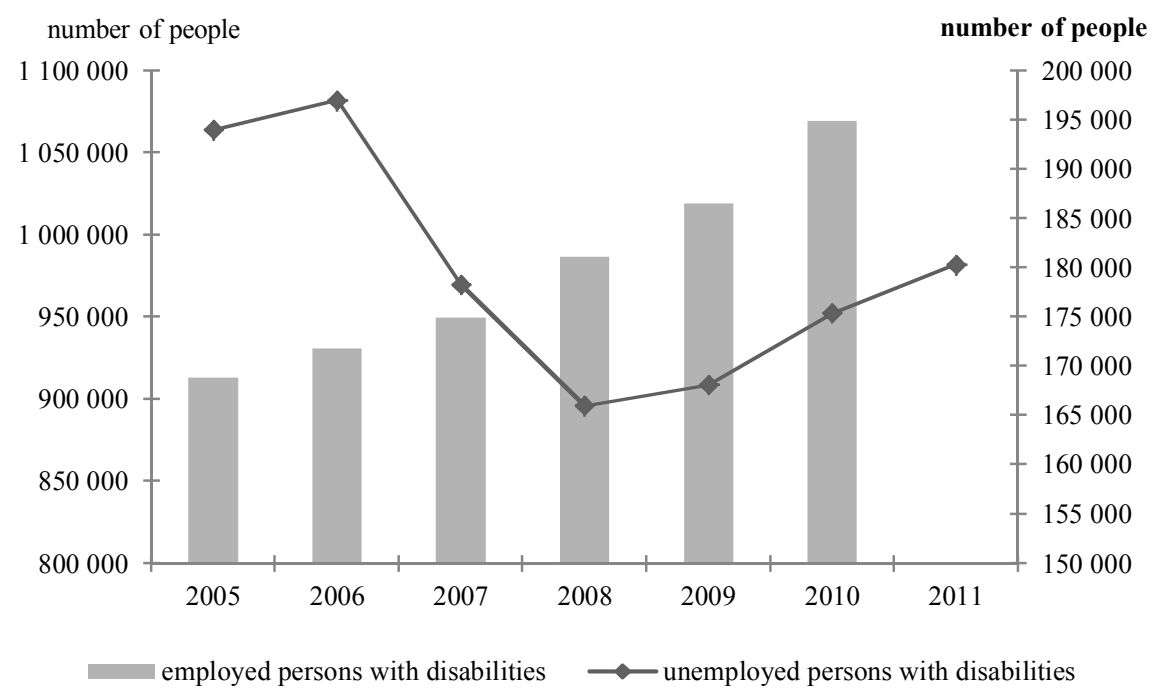

Source: Own study based on Amtliche Nachrichten der Bundesagentur... (2011, p. 141); Amtliche Nachrichten der Bundesagentur... (2012, p. 147).

One of the instruments aiming at supporting and intensifying integration of people with disabilities on the labor market, from professional training to providing employment, is „,personal budget” (persönliches Budget) under $\S$ $17 S G B I X$. This instrument supports mostly young people, who are assisted by social workers in the process. The workers' task is supporting professional orientation and professional training, as well as possible acquisition of qualifications in order to commence work (Zielvereinbarung Persönliches Budget). Personal budget should also support the right to personal autonomy.

A favored and recommended solution is also supported employment, which may be the result of the efforts undertaken in the framework of a personal budget, it may also be an alternative to employ in sheltered workshops. Supported employment is the employment of people with disabilities in the open labor market with the help of a job coach. This solution is also used in Poland (Boguszewska, Dunaj 2011).

Facilitating inclusion of people with disabilities in the labor market can be subsidized in the form of the abovementioned allowance. As an exemption from the limit defining period of time, when the employer can obtain support for the people with disabilities defined by legal regulations, such subsidy can amount to $70 \%$ of salary, and may be extended from 24 months to 96 months ( $\$ 90$ SGB III). 
In 2013, it is difficult to assess the impact of the reform on the situation in the labor market, as between 2009-2011, the period of deepest recession, far more money was allocated for active policy in the labor market, compared to the previous years. However, in 2012 and 2013, certain previous programs have not been supported at all, or only marginally. The biggest drop in financing in April 2013 r., comparing with 2012, was observed in support for self-employment and pre-retirement programs; limited for financing employment. On the other hand, employment of the people with disabilities has been facilitated, there has been a rise in expenses on vocational activation and training, including people with disabilities. In this period of time, $11 \%$ fewer people took part in active programs on the labor market (Der Arbeits... 2013).

\section{Employment of People with Disabilities in Poland and Germany - Similarities and Differences}

In both countries, people with disabilities are protected by law. In Poland, in accordance with art. 28 item 1 Act dated 27 August 1997 on social and professional rehabilitation and employing people with disabilities (Journal of Laws of 2010), in order to obtain the status of sheltered workshops, the employer has to meet the requirements regarding:

- employment rate for people with disabilities - must be at least $40 \%$ of all employees, $10 \%$ must be people with severe or moderate disability,

- working premises (health and safety regulations, workplace, sanitation, etc. - adjustment to the needs of the disabled),

- providing medical services, counselling and rehabilitation.

The basic differences between the countries stem from different classification of enterprises. In Germany, sheltered workshops are created only for the purpose of employing people with disabilities (at least 120 disabled employees), the number of the employees is defined by law, e.g. 1:12 ratio in production department, 1:6 in professional training department. Other selected similarities and differences are presented in Table 6. 
Table 6. Selected similarities and differences

\begin{tabular}{|l|}
\hline \multicolumn{1}{|c|}{ Similarities } \\
\hline \multicolumn{1}{|c|}{ Permany } \\
\hline $\begin{array}{l}\text { Financial support for employers - adaptation of the workplace to the needs of disabled } \\
\text { employee, tax exemption }\end{array}$ \\
\hline $\begin{array}{l}\text { The similarities arising from the content of the relevant laws, such as priority in em- } \\
\text { ployment in the civil service, if there are no more than five candidates who meet the } \\
\text { requirements for the position (fulfilling other criteria), it is obligatory to employ a person } \\
\text { with a disability, or, alternatively, pay charge to Office for Integration in Germany, or } \\
\text { PFRON in Poland }\end{array}$ \\
\hline Additional holidays (5 days in Germany, 10 in Poland) \\
\hline Income not enough to cover costs of living; contributions for social security system. \\
\hline $\begin{array}{l}\text { Before ratification of Convention on the Rights of Persons with Disabilities there were } \\
\text { certain regulations employment of people with disabilities - in Germany since 1974in } \\
\text { Poland, among others, Regulation no. 281 by Council of Ministers dated 13.12.1973 on } \\
\text { ensuring conditions for further development of disabled people cooperatives, Act no. 201 } \\
\text { dated 9.5.1991 on employment and professional rehabilitation of people with disabilities. }\end{array}$ \\
\hline \multicolumn{2}{|c|}{ Differences } \\
\hline $\begin{array}{l}\text { Ratification of Convention on the Rights of } \\
\text { Persons with Disabilities in 2009. }\end{array}$ \\
\hline
\end{tabular}

Source: Own study based on applicable legal regulations.

The main differences also include the forms of entities that employ people with disabilities. In Poland in 2012 and in the first quarter of 2013 there were approximately 1,400 sheltered workshops (their definition is given above), about 250 invalids' cooperatives and 663 occupational therapy workshops (they are not companies). The first two types of institutions are also sheltered workshops, but not all sheltered workshops are invalids' cooperatives (the differences are connected with the form of ownership and rules of management) (SODiR PFRON). It is worth mentioning that the model of functioning of Polish invalids' cooperatives and the blind's cooperatives in the 70's of the twentieth century, WHO considered worthy to follow because "in a comprehensive way it covered all the essential elements of rehabilitation such as education, work, medical care and participation in social life" (Mizera 2011).

In order to promote the employment of people with disabilities in the open labor market, since 2004 Poland has introduced co-financing of the wages of people with disabilities, since 2008 it has been in the form of wage subsidies. From 2004 to 2012 the number of people with disabilities employed in the labor market quadrupled.

The strategic objectives in Poland include the achievement of $40 \%$ of professional activity among people with disabilities. Summarized in Table 7 , the employment and unemployment rates for both countries, however, show a high potential to catch up in this area. Education and employment 
systems implemented so far in both countries, precluded protection, or at least did not integrate people with disabilities in the same way as in countries that do not have special schools or special forms of employment for people with disabilities.

Table 7. Selected market and work indicators for general population and people with disabilities in 2011

\begin{tabular}{|l|c|c|c|c|}
\hline \multirow{2}{*}{ Specification } & \multicolumn{2}{|c|}{ Poland } & \multicolumn{2}{c|}{ Germany } \\
\cline { 2 - 5 } & $\begin{array}{c}\text { Population } \\
\text { in total }\end{array}$ & $\begin{array}{c}\text { Disabled } \\
\text { citizens }\end{array}$ & $\begin{array}{c}\text { Population in } \\
\text { total }\end{array}$ & $\begin{array}{c}\text { Disabled } \\
\text { citizens }\end{array}$ \\
\hline $\begin{array}{l}\text { Professional } \\
\text { activity rate }\end{array}$ & $56.0 \%$ & $17.2 \%$ & 72.5 & - \\
\hline $\begin{array}{l}\text { Employment } \\
\text { rate }\end{array}$ & $50.7 \%$ & $14.8 \%$ & $52.1 \%$ & $17 \%(2010)$ \\
\hline $\begin{array}{l}\text { Unemployment } \\
\text { rate }\end{array}$ & $9.5 \%$ & $13.7 \%$ & $7.1 \%$ & $5.6 \%$ \\
\hline
\end{tabular}

Source: Persons with disabilities... (2012, p. 29); Der Arbeitsmarkt in Deutschland... (2012, p.12, 22); Der Arbeitsmarkt für schwerbehinderte... (2012).

\section{Conclusions}

Ratification of The Convention on the Rights of Persons with Disabilities in Poland and Germany, strategic objectives adopted by the EU, implementation of the demands of equality and non-discrimination as well as changes in the labor market determine by the evolution of the approach to the employment of people with disabilities.

Systems of supporting the inclusion of people with disabilities in the labor market are similar in Poland and Germany. The main incentives for employers in the open labor market in both countries include primarily the introduction of financial incentives, such as bonuses to salaries, funds for social security contributions and/or no obligation to pay mandatory contributions in case of employing a different number of the disabled in the company from what is provided for in the act. On the other hand, these incentives mean allowing people with severe disability to participate in the society by providing them with adequate forms of employment, not only in the form of paid work, but also in the form of occupational therapy undertaken in facilities and workshops accessible for the disabled.

Conclusions from the analysis and interviews conducted with experts confirmed the thesis of the paper and showed that due to the ageing population, the number of people with disabilities in society will increase, also due to chronic diseases and/or civilization diseases. Allowing these people to 
remain in the labor market or their reintegration is becoming increasingly important. Especially for the people with mild to moderate disability, supported employment may be an option more suited to their abilities than employment in a sheltered workshop. In both countries, there is still great potential to realize inclusion of people with disabilities, not only into the labor market, but also into the society.

\section{References}

Amtliche Nachrichten der Bundesagentur für Arbeit. Arbeitsmarkt 2010 (2011), Bundesagentur für Arbeit. Nürnberg.

Amtliche Nachrichten der Bundesagentur für Arbeit, Arbeitsmarkt 2011 (2012), Bundesagentur für Arbeit. Nürnberg.

Boguszewska K., Dunaj M. et.al. (2011), Zatrudnienie wspomagane. Materiaty konferencyjne, Ministerstwo Pracy i Polityki Społecznej Biuro Pełnomocnika Rządu do Spraw Osób Niepełnosprawnych. Warszawa.

British Medical Bulletin (2013), Oxford University, http://bmb.oxfordjournals. org/content/77-78/1/55/F1.expansion.html.

Constitution of the World Health Organization, signed on 22 July 1946. http://apps.who.int/gb/bd/PDF/bd47-/EN/constitution-en.pdf.

The Convention on the Rights of Persons with Disabilities, written in New York on 13.12.2006 r. Journal of Laws of 25 October 2012.

Das Trägerübergreifenden Persönliche Budget (2012), Bundesministerium für Arbeit und Soziales. Bonn.

Der Arbeits- und Ausbildungsmarkt in Deutschland. April 2013 (2013), Bundesagentur für Arbeit. Nürnberg.

Der Arbeitsmarkt für schwerbehinderte Menschen (2012), Bundesagentur für Arbeit. Nürnberg.

Der Arbeitsmarkt in Deutschland, Arbeitsmarktberichterstattung - Juni 2012 (2012), Bundesagentur für Arbeit. Nürnberg.

Detmar W., German M. et.al. (2008), Entwicklung der Zugangszahlen zu Werkstätten für behinderte Menschen, ISB - Gesellschaft für Integration, Sozialforschung und Betriebspädagogik gGmbH. Berlin.

Die Behindertenwerkstätten sind zu modernen Betrieben geworden. Frankfurter Allgemeine Zeitung. 01.10.1996. No. 229. online-Archiv http://www.seiten.fazarchiv.de/faz/19961001/f19961001werk---100.htm.

Dreher W., Platte A., Seitz I. Konzepte sonderpädagogischer Erziehung, Bildung und Unterrichtung, BIFIE - Bundesinstitut für Bildungsforschung, Innovation und Entwicklung des österreichischen Schulwesenshttps://www.bifie. at/buch/1024/4. 
Gesetz zu dem Übereinkommen der Vereinten Nationen vom 13.12.2006 über die Rechte von Menschen mit Behinderungen sowie zu dem Fakultativprotokoll vom 13.12.2006 zum Übereinkommen der Vereinten Nationen über die Rechte von Menschen mit Behinderungen (2008), Bundesgesetzblatt Jahrgang 2008 Teil II Nr. 35. Bonn.

Gesetz zur Verbesserung der Eingliederungschancen am Arbeitsmarkt (2011), Bundesgesetzblatt Jahrgang 2011 Teil I Nr. 69. Bonn.

Gesetzentwurf der Bundesregierung für ein Gesetz zur Verbesserung der Eingliederungschancen am Arbeitsmarkt. Begründung. http://www.arbeitsagentur.de/ zentraler-Content/A05-Berufl-Qualifizierung/A052-Arbeitnehmer/Publikation/pd $\mathrm{f} /$ Gesetzesbegruendung-Verbesserung-Eingliederungschancen.pdf.

HEGA 06/2010, Fachkonzept für Eingangsverfahren und Berufsbildungsbereich in Werkstätten für behinderte Menschen (WfbM) (2010), Bundesagentur für Arbeit. Nürnberg.

International Classification of Functioning, Disability and Handicaps (ICIDH) (2001), World Health Organization Geneva 2001.

International Classification of Impairments, Disabilities and Handicaps (ICIDH), http://www.-aihw.gov.au/WorkArea/DownloadAsset.aspx?id=6442455478.

Kunz A. (2013), Anspruch ohne Wirklichkei, „Wirtschaftwoche“, No. 8.

Leyen von der U. (2011), Brief an die Mitglieder der Fraktionen der CDU/CSU und der FDP im Deutschen Bundestag. 25.5.2011, Berlin, http://www.lag-arbeithessen.net/fileadmin/user_upload/VdLeyen_-Brief_an_RegFraktionen_zu_ Instrumentenreform_250511.pdf.

Mapping the Implementation of Policy for Inclusive Education (MIPIE), An exploration of challenges and opportunities for developing indicators (2011), European Agency for Development in Special Needs Education.

Mizera L. (2011), System wspierania rehabilitacji zawodowej osób niepetnosprawnych w Polsce, Krajowy Związek Rewizyjny Spółdzielni Inwalidów i Spółdzielni Niewidomych, Warszawa.

SODiR PFRON (2013), http://www.niepelnosprawni.gov.pl/niepelnosprawnosc-wliczbach-/sod-pfron/.

Sozialgesetzbuch (SGB) Drittes Buch (III) - Arbeitsförderung - (SGB III) (2013), BGBl I.

Sozialgesetzbuch (SGB) Neuntes Buch (IX) - Rehabilitation und Teilhabe behinderter Menschen - (SGB IX) (2001) - (Artikel 1 des Gesetzes v. 19.6.2001. BGBl. I.

Übereinkommen der Vereinten Nationen über Rechte von Menschen mit Behinderungen. Erster Staatenbericht der BRD. 3.8.2011 (2011), Bundesministerium für Arbeit und Soziales. Berlin.

Verzeichnis der anerkannten Werkstätten für behinderte Menschen (2012), Bundesagentur für Arbeit Nürnberg. April 2012. Institut der deutschen Wirtschaft Köln -REHADAT 2012. 
Werkstätten werden zu Dienstleistern der Wirtschaft. http://www.handelsblatt.com /unternehmen/management/strategie/soziale-einrichtungen-werkstaetten-werdenzu-dienstleistern-der-wirtschaft/6332294-2.html, Handelsblatt (18.3.12).

Werkstättenverordnung from 13.8.1980, BGB1. I with further amendments of 22.12.2008. BGB1. I.

Westecker M., Voß N. (ed.) (2011), Leben mit Behinderung, 53 Nord Agentur und Verlag. Hamburg.

World Report on Disability 2011 (2011), World Health Organization \& The World Bank. Geneva. 